\title{
Creating efficiency model of higher education institutions
}

\author{
Jana Janikova ${ }^{1, *}$ \\ ${ }^{1}$ Institute of Technology and Business, School of V aluation and Expertness, O kruzni 517/10, 37001 \\ Ceske Budejovice, Czech Republic
}

\begin{abstract}
The paper deals with assessing the efficiency of the faculties of universities of applied sciences. A model based on Data Envelopment A nalysis was created, using specifically the CCR alternative. It is an inputoriented method, assuming the constant returns to scale. The model was subsequently validated on an example of a specific university. The results clearly show that the model was able to determine how and to which extent a given faculty is effective. It also provides the assessor with a tool to manage the efficiency of the faculty, as it is able to identify the causes of possible ineffectiveness. Further research focuses on the model's applicability in the environment of all universities of applied sciences ideally all over the world.
\end{abstract}

Keywords: Data Envelopment A nalysis, measuring efficiency, efficiency, university of applied sciences

\section{Introduction}

Measuring of management efficiency in the environment of universities of applied sciences (hereinafter referred to as UAS) is carried out in a specific way different from commonly used tools, and may even give room for their creative interpretation [1]. In the absence of market mechanisms for price educational outputs, Avkirant [2] states that UAS have to find alternative methods for measuring their management efficiency. A different form of financing UAS brings various views of assessing the efficiency of using public resources.

There are a number of methods to be used, e.g. historical and logical method, systemic approach, documentary analysis, observations, and interviews. Mora et al. [3] use these methods to analyse the distribution of funds to universities in Ecuador and find that UAS in Ecuador have a suitable tool for distributing these funds. Tran [4] deals with the analysis of the management of Japanese UAS and considers the mere distribution of state funds provided to UAS to be inefficient due to their different characteristics. In this context, in the CR, there was created "White Book", which served as a basis for the reform of the Czech tertiary education system. According to the Ministry of Education, Youth, and Sports [5], the goal was the stabilization and competitiveness of UAS on a global scale. There were created individual segments of UAS, thus improving the efficiency of UAS management in the CR.

\footnotetext{
* Corresponding author: janikova@ mail.vstecb.cz
} 
Fund from the state budget are allocated to individual UAS based on the share they have on the overall performance of all UAS.

Kowang et al. [6] deal with the massive reduction of the operating budget in Malaysia after 2016 and seeks new approaches to sustain stable growth in education and research. Sustainability is in the continuous creation of values in line with the Lean Six Sigma concept (hereinafter referred to as LSS). According to Kowang et al. [6], the goal of the LSS concept is to categorize UAS expenditures with added value, without added value, and operational added value.

The efficiency of public tertiary education across the EU countries, Japan, and the USA is analysed by St. Aubyn et al. [7] using semi-parametric methods and stochastic boundary analysis. The authors also compare resources with outcomes and results of education and research.

Zhang et al. [8] compare inputs in the form of research expenditures with outputs on the example of three research universities in Atlanta and Georgia in the period of 2002-2015, which covers the period before and after the economic crisis. Zhang et al. [8] argue that despite more intensive research funding after the economic crisis, it has not been possible to add value to the research outputs; according to the authors, there are many relevant factors to be considered which limit research activities of the academic and scientific workers.

In their study on the efficiency of UAS in Romania, Munteanu and Andrei-Coman [9] present an original overview of modern methods for assessing the efficiency of UAS. Mikušová [10] deals with the efficiency of resource processing and the question to what extent inefficient UAS in the CR should change the outputs to be efficient, for which she uses Data Envelope Analysis (hereinafter referred to as DEA). In DEA, Mikušová [10] uses the efficiency of education as an outcome. DEA was also used by Avkiran [2], Abbot and Doucouliagos [11] to measure the efficiency of individual Australian universities. The efficiency of Thai UAS using DEA is examined by Kantabutra and Tang [12]. According to Mikušová [10], DEA assesses the technical efficiency of homogeneous units such as schools, hospitals, banks, etc.; however, there are aspects to be considered. Pietrzak [13], Mikušová [10] recommend the division of the units into sub-groups by their specialization or faculties/departments. This ensures better homogeneity, thus providing better informative capability of the analysis results. On the other hand, Mikušová [10] or Klieštik [14, 15] believes that the availability of data of faculties or departments may play a decisive role. Flegg et al. [16] define the technical efficiency of homogeneous units as a ratio of a weighted sum of outputs to a weighted sum of inputs. The set of permissible options in DEA models is determined by the efficient frontier. According to Jablonský and Dlouhý [17], efficient units are those at this efficient frontier. Due to empirical orientation and the lack of necessity to include a wide range of a priori assumptions, Cooper et al. [18] defines DEA as a multilateral instrument to assess problems in various contexts. Jablonský and Dlouhý [17] argue the following prerequisites need to be met in order to use the DEA method:

- homogeneous production units,

- preferably lower inputs and higher outputs,

- appropriate inputs and outputs,

- semi-positive data (each production unit has at least one positive input and one positive output).

DEA meets all criteria for a proper determination of UAS efficiency, including the assessment of the individual UAS segments. The method is suitable also due to well-prepared methodology; however, as already mentioned, the data for certain organizational segments of UAS are not easily available.

The objective of the paper is to create a model of assessing efficiency of UAS based on the DEA method. 


\section{Data and methods}

The outputs will be set according to their positive influence on the efficiency of management of the assessed faculties at the Institute of Technology and Business (hereinafter referred to as ITB). The analysis inputs are the funds used for personnel costs, costs of material, services, and fixed assets. The outputs will be the funds used for pedagogical, and contract activities of the individual faculties. For their processing, there will be used ITB data obtained from the iFIS (Integrated Financial Information System - an accounting module).

The efficiency of individual faculties will be measured and compared for the period of 2017 - 2019. For assessment of efficiency, an input-oriented CCR model with assumed constant return on scale will be used.

Efficiency is defined as a ratio of one input and one output, calculated using the following formula:

$$
\text { efficiency }=\frac{\text { output }}{\text { input }}
$$

To assess the efficiency rate in practice, it is necessary to consider more than one input or output; the following formula is used:

$$
\text { efficiency rate }=\frac{\text { weighted sum of outputs }}{\text { weighted sum of inputs }} \text {. }
$$

Effective units with the highest value of efficiency determine the efficiency frontier. The units at this frontier are referred to as efficient, and will be compared with the others. Efficient unit is a unit that cannot use less inputs for the production of the same outputs, or a unit that cannot achieve higher outputs using the same inputs.

In the paper, there is used an input-oriented CCR model with assumed constant return on scale, that is, the number of outputs is directly changed with the change in the number of inputs. Technical efficiency is calculated as a ratio of a weighted sum of outputs to a weighted sum of inputs. The coefficients sought are those at the interval of $\langle 0,1\rangle$, where the units with the coefficient of 1 are efficient, while those with lower coefficients are considered inefficient. The model determines the necessary reduction of inputs to ensure the efficiency of the monitored units.

The efficiency is assessed for four inputs and three outputs, with the inputs being personnel costs, costs of material, services, and fixed assets (tangible and intangible). The outputs are funds obtained for creative, pedagogical, and contract activities of faculties. There are three ITB faculties, whose efficiency is being examined: Faculty of Corporate Strategy (hereinafter referred to as FCS), Faculty of Technology (FT), and School of Expertness and Valuation (SEV). Their efficiency is examined for the period of 2017-2019.

In the CCR model, the unknown variables are assigned input weights I and output weights $\mathrm{j}$ with a unit k. For each unit (faculty), a separate model is created. The model for a set of units is based on the following objective function:

$$
\mathrm{e}_{\mathrm{H}}=\frac{\sum_{\mathrm{j}=1}^{\mathrm{n}} \mathrm{u}_{\mathrm{jH}} \mathrm{y}_{\mathrm{jH}}}{\sum_{\mathrm{i}=1}^{\mathrm{m}} \mathrm{v}_{\mathrm{iH}} \mathrm{x}_{\mathrm{iH}}} \rightarrow \max
$$

where the set contains the $\mathrm{p}$ number of units, while $\mathrm{H}$ is one of the $\mathrm{p}$ units. The function maximizes the ratio of weighted inputs and weighted outputs.

The function has the following limits:

$$
\frac{\sum_{j=1}^{n} u_{j H} y_{j H}}{\sum_{i=1}^{m} v_{i H} x_{i H}} \leq 1, \forall k=1,2, \ldots, p .
$$


The limits ensure that the ratio of inputs to outputs with the weights for the k-th unit was lower than or equal to 1 .

Another limit is a non-negative condition, which ensures non-negativity of the unknown variables sought, specifically the weights:

$$
\begin{aligned}
& u_{j \mathrm{H}} \geq 0, \forall \mathrm{j}=1,2, \ldots, \mathrm{n}, \\
& \mathrm{v}_{\mathrm{iH}} \geq 0, \forall \mathrm{i}=1,2, \ldots, \mathrm{m} .
\end{aligned}
$$

The model can be modified to linear by maximizing the numerator of the objective function if the denominator equals 1 .

$$
\begin{gathered}
\mathrm{e}_{\mathrm{H}}=\sum_{\mathrm{j}=1}^{\mathrm{n}} \mathrm{u}_{\mathrm{jH}} \mathrm{y}_{\mathrm{jH}} \rightarrow \max \\
\sum_{\mathrm{i}=1}^{\mathrm{m}} \mathrm{v}_{\mathrm{iH}} \mathrm{x}_{\mathrm{iH}}=1 \\
-\sum_{\mathrm{i}=1}^{\mathrm{m}} \mathrm{v}_{\mathrm{iH}} \mathrm{x}_{\mathrm{ik}}+\sum_{\mathrm{j}=1}^{\mathrm{n}} \mathrm{u}_{\mathrm{jH}} \mathrm{y}_{\mathrm{jk}} \leq 0, \forall \mathrm{k}=1,2, \ldots, \mathrm{p}, \\
\mathrm{u}_{\mathrm{jH}} \geq 0, \forall \mathrm{j}=1,2, \ldots, \mathrm{n}, \\
\mathrm{v}_{\mathrm{iH}} \geq 0, \forall \mathrm{i}=1,2, \ldots, \mathrm{m} .
\end{gathered}
$$

The assumption is that the unit $\mathrm{H}$ is inefficient. By creating a dual model for the primary model, it is possible to identify the units that form a set of model units of the inefficient unit, thus obtaining the coefficients $\lambda \mathrm{kH}$ of the combination of model units that create a virtual efficient unit to the unit $\mathrm{H}$.

The objective function of the dual model is as follows:

$$
\mathrm{z}_{\mathrm{H}} \rightarrow \min \text {. }
$$

The limits for this function are as follows:

$$
\begin{aligned}
& \mathrm{x}_{\mathrm{iH}} \mathrm{z}_{\mathrm{H}}-\sum_{\mathrm{k}=1}^{\mathrm{p}} \lambda_{\mathrm{kH}} \mathrm{x}_{\mathrm{ik}} \geq 0, \forall \mathrm{i}=1,2, \ldots, \mathrm{m}, \\
& \sum_{\mathrm{k}=1}^{\mathrm{p}} \lambda_{\mathrm{kH}} \mathrm{y}_{\mathrm{jk}} \geq \mathrm{y}_{\mathrm{jH}}, \forall \mathrm{j}=1,2, \ldots, \mathrm{n}, \\
& \lambda_{\mathrm{kH}} \geq 0, \forall \mathrm{k}=1,2, \ldots, \mathrm{p} .
\end{aligned}
$$

The variable $\mathrm{zH}$ takes arbitrary values.

The value of inputs and outputs of the unit is calculated as a combination of inputs and outputs of model units.

For inputs:

$$
\mathrm{x}_{\mathrm{iH}}^{\prime}=\sum_{\mathrm{k}=1}^{\mathrm{p}} \lambda_{\mathrm{kH}} \mathrm{x}_{\mathrm{ik}} ; \mathrm{i}=1,2, \ldots, \mathrm{m} .
$$

For outputs:

$$
\mathrm{y}_{\mathrm{jH}}^{\prime}=\sum_{\mathrm{k}=1}^{\mathrm{p}} \lambda_{\mathrm{kH}} \mathrm{y}_{\mathrm{jk}} ; j=1,2, \ldots, n .
$$

The tasks will be solved in the add-in program MS Excel Solver. After the creation of a table from the inputs and outputs, variables - individual weights will be designated in MS Excel. The column "Conditions" will contain the individual functions, which are based on the selected model.

\section{Results}

The model was applied to the example of the Institute of Technology and Business in České Budějovice for the period of 2017-2019. 


\subsection{Assessment of faculty efficiency for the year 2017}

The inputs for the assessment of ITB faculties for the year 2017 are the data given in Table 1.

Table 1. Inputs for specific example of ITB faculties for the year 2017

\begin{tabular}{|c|c|c|c|c|}
\hline Faculty & $\begin{array}{c}\text { Material } \\
\text { consumption } \\
\text { (in CZK } \\
\text { million) }\end{array}$ & $\begin{array}{c}\text { Personnel } \\
\text { costs } \\
\text { (in CZK } \\
\text { million) }\end{array}$ & $\begin{array}{c}\text { Fixed assets } \\
\text { (in CZK million) }\end{array}$ & $\begin{array}{c}\text { Services } \\
\text { consumption } \\
\text { (in CZK } \\
\text { million) }\end{array}$ \\
\hline Identifier of input & $\mathbf{v}$ 1 & $\mathbf{v} 2$ & $\mathbf{v 3}$ & $\mathbf{V}$ 4 \\
\hline FCS & 0.293 & 24.402 & 0.000 & 2.990 \\
\hline FT & 0.167 & 24.155 & 0.000 & 2.954 \\
\hline SEV & 0.097 & 4.575 & 0.000 & 0.571 \\
\hline
\end{tabular}

Source: iFIS ITB, own processing.

The outputs of specific assessment of ITB faculties for the year 2017 are the data presented in Table 2.

Table 2. Outputs for specific case of ITB faculties for the year 2017

\begin{tabular}{|c|c|c|c|}
\hline Faculty & $\begin{array}{c}\text { Funds for creative } \\
\text { activities } \\
\text { (in CZK million) }\end{array}$ & $\begin{array}{c}\text { Funds for } \\
\text { pedagogical } \\
\text { activities } \\
\text { (in CZK million) }\end{array}$ & $\begin{array}{c}\text { Funds obtained from } \\
\text { contract activities } \\
\text { (in CZK million) }\end{array}$ \\
\hline Identifier of input & $\mathbf{u} 1$ & $\mathbf{u}_{2}$ & $\mathbf{u}_{3}$ \\
\hline FCS & 9.605 & 6.714 & 0.010 \\
\hline FT & 8.965 & 12.453 & 0.598 \\
\hline SEV & 2.787 & 0.735 & 1.019 \\
\hline
\end{tabular}

Source: iFIS ITB, own processing.

As three faculties are being assessed, three models need to be created. Faculty efficiency is marked e and an order number.

The first faculty assessed in 2017 is FCS. In the case of the primary model, the result of the efficiency assessment is given in Table 3.

Table 3. Results of assessing primary model for FCS

\begin{tabular}{|c|c|}
\hline Variable & Value \\
\hline $\mathrm{e}_{1}-$ faculty efficiency & 0.866 \\
\hline $\mathrm{u}_{1}-$ funds for creative activities & 0.090 \\
\hline $\mathrm{u}_{2}-$ funds for pedagogical activities & 0.000 \\
\hline
\end{tabular}




\begin{tabular}{|c|c|}
\hline $\mathrm{u}_{3}-$ funds obtained from contract activities & 0.000 \\
\hline $\mathrm{V} 1-$ material consumption & 1.468 \\
\hline $\mathrm{V} 2-$ personnel costs & 0.000 \\
\hline $\mathrm{V} 3-$ fixed assets & 0.000 \\
\hline $\mathrm{V} 4-$ services consumption & 0.191 \\
\hline
\end{tabular}

Source: 0 wn processing.

The table above indicates that FCS is not efficient, as the value of $\mathrm{e}_{1}$ is lower than 1 . For this reason, a dual model is created. Its creation enables obtaining a suitable combination to achieve the efficiency of FCS. The result of the dual model for assessing FCS efficiency for the year 2017 is presented in Table 4.

Table 4. Result of assessing dual model for FCS

\begin{tabular}{|c|c|}
\hline Variable & Value \\
\hline $\mathrm{z}_{1}$ & 0.866 \\
\hline$\lambda_{1}$ & 0.000 \\
\hline$\lambda_{2}$ & 0.556 \\
\hline$\lambda_{3}$ & 1.658 \\
\hline
\end{tabular}

Source: Own processing.

The results indicate that the model using for FCS is FT and SEV, as the value of their variables is not zero. To obtain the optimal value of inputs for FCS, the coefficients are multiplied by the inputs of FT and SEV (efficient units). The optimal values of inputs are shown in Table 5.

Table 5. Optimal values of inputs for FCS

\begin{tabular}{|c|c|}
\hline Input & Optimal value \\
\hline Material consumption (in CZK million) & 0.254 \\
\hline Personnel costs (in CZK million) & 21.013 \\
\hline Fixed assets (in CZK million) & 0.000 \\
\hline Services consumption (in CZK million) & 2.589 \\
\hline
\end{tabular}

Source: Own processing.

To be efficient in comparison with FT and SEV, FCS should reduce the consumption of material from the initial CZK 0.293 million to CZK 0.254 million, i.e. by CZK 39 thousand. In the case of personnel costs, there should be a decrease by CZK 3.389 million (from CZK 24.402 million to CZK 21.013 million). No reduction is necessary for fixed assets, as there was no fixed asset purchased in 2017. In the case of services consumption, the faculty should reduce the initial CZK 2.990 million to CZK 2.589 million, i.e. by 0.401 million.

The second faculty assessed in 2017 is FT. According to the results obtained, FT is efficient, as the value of $e_{2}$ equals 1 . The important input for FT is $v_{2}$, personnel costs (with 
a value of 0.041 ). The important source for the $\mathrm{FT}$ model is the output $\mathrm{u}_{2}$, funds for pedagogical activities (with a value of 0.080 ).

The third faculty assessed in 2017 is SEV. The results show that SEV is efficient, since the value of $e_{3}$ is 1 . The important input for the model of SEV is $v_{2}-$ personnel costs (with a value of 0.219 ), while the important source is the output $\mathrm{u}_{1}$ - funds for creative activities (with a value of 0.359 ).

\subsection{Assessment faculty efficiency for the year 2018}

The inputs for specific assessment of ITB faculties for the year 2018 are the data given in Table 6.

Table 6. Inputs for ITB faculties for the year 2018

\begin{tabular}{|c|c|c|c|c|}
\hline Faculty & $\begin{array}{c}\text { Material } \\
\text { consumption } \\
\text { (in CZK } \\
\text { million) }\end{array}$ & $\begin{array}{c}\text { Personnel } \\
\text { costs } \\
\text { (in CZK } \\
\text { million) }\end{array}$ & $\begin{array}{c}\text { Fixed assets } \\
\text { (in CZK } \\
\text { million) }\end{array}$ & $\begin{array}{c}\text { Services } \\
\text { consumption (in } \\
\text { CZK million) }\end{array}$ \\
\hline Identifier of input & $\mathbf{v}_{\mathbf{1}}$ & $\mathbf{\mathbf { v } _ { 2 }}$ & $\mathbf{\mathbf { v } _ { 3 }}$ & $\mathbf{\mathbf { v }}$ \\
\hline FCS & 0.144 & 25.150 & 0.000 & 2.871 \\
\hline FT & 0.492 & 35.973 & 15.608 & 2.544 \\
\hline SEV & 0.040 & 6.205 & 0.000 & 1.037 \\
\hline
\end{tabular}

Source: iFIS ITB, own processing.

The inputs for the specific assessment of ITB faculties for the year 2018 are the data given in Table 7.

Table 7. Inputs for ITB faculties for the year 2018

\begin{tabular}{|c|c|c|c|}
\hline Faculty & $\begin{array}{c}\text { Funds for creative } \\
\text { activities } \\
\text { (in CZK million) }\end{array}$ & $\begin{array}{c}\text { Funds for } \\
\text { pedagogical } \\
\text { activities } \\
\text { (in CZK million) }\end{array}$ & $\begin{array}{c}\text { Funds obtained from } \\
\text { contract activities } \\
\text { (in CZK million) }\end{array}$ \\
\hline Identifier of input & $\mathbf{u}_{\mathbf{1}}$ & $\mathbf{u}_{\mathbf{2}}$ & $\mathbf{u}_{\mathbf{3}}$ \\
\hline FCS & 9.795 & 12.137 & 0.000 \\
\hline FT & 9.742 & 15.771 & 1.913 \\
\hline SEV & 3.458 & 0.643 & 1.202 \\
\hline
\end{tabular}

Source: iFIS ITB, own processing.

As three faculties are assessed, three models need to be created. Faculty efficiency is marked e and an order number.

The first faculty assessed in 2018 is FCS. The results of the primary model show that FCS is efficient, since the value of $e_{1}$ is 1 . The important input for the model of FCS is $v_{2}-$ personnel costs (with a value of 0.040). The important source for the model of FCS is the output $\mathrm{u}_{2}-$ funds for pedagogical activities (with a value of 0.082 ).

The second faculty assessed in 2018 is FT. The results indicate that FT is efficient, since the value of $e_{2}$ is 1 . The important input for the model of FT is $v_{2}-$ personnel costs (with a value of 0.028 ). The important source for the model of FT is the output $\mathrm{u}_{2}-$ funds for 
pedagogical activities (with a value of 0.058 ) and $\mathrm{u}_{3}$ - funds obtained from contract activities (with a value of 0.048 ).

The third faculty assessed in 2018 is SEV. The results show that SEV is efficient, since the value of $e_{3}$ is 1 . The important input for the model of SEV is $v_{2}-$ personnel costs (with a value of 0.161 ). The important source for the model of SEV is the output $\mathrm{u}_{1}-$ funds for creative activities (with a value of 0.289 ).

\subsection{Assessment of faculty efficiency for the year $\mathbf{2 0 1 9}$}

The inputs for the specific assessment of ITB faculties for the year 2019 are the data presented in Table 8 .

Table 8. Inputs for ITB faculties for the year 2019

\begin{tabular}{|c|c|c|c|c|}
\hline Faculty & $\begin{array}{c}\text { Material } \\
\text { consumption } \\
\text { (in CZK } \\
\text { million) }\end{array}$ & $\begin{array}{c}\text { Personnel } \\
\text { costs } \\
\text { (in CZK } \\
\text { million) }\end{array}$ & $\begin{array}{c}\text { Fixed assets } \\
\text { (in CZK } \\
\text { million) }\end{array}$ & $\begin{array}{c}\text { Services } \\
\text { consumption } \\
\text { (in CZK } \\
\text { million) }\end{array}$ \\
\hline Identifier of input & $\mathbf{v}$ 1 & $\mathbf{v}_{\mathbf{2}}$ & $\mathbf{v}$ 3 & $\mathbf{v}_{\mathbf{4}}$ \\
\hline FCS & 0.167 & 22.015 & 0.212 & 3.134 \\
\hline FT & 0.948 & 43.052 & 5.788 & 4.439 \\
\hline SEV & 0.052 & 7.794 & 0.000 & 0.991 \\
\hline
\end{tabular}

Source: iFIS ITB, own processing.

The outputs for the specific assessment of ITB faculties for the year 2019 are the data presented in Table 9.

Table 9. Outputs for ITB faculties for the year 2019

\begin{tabular}{|c|c|c|c|}
\hline Faculty & $\begin{array}{c}\text { Funds for creative } \\
\text { activities } \\
\text { (in CZK million) }\end{array}$ & $\begin{array}{c}\text { Funds for } \\
\text { pedagogical } \\
\text { activities } \\
\text { (in CZK million) }\end{array}$ & $\begin{array}{c}\text { Funds obtained from } \\
\text { contract activities } \\
\text { (in CZK million) }\end{array}$ \\
\hline Identifier of input & $\mathbf{u}_{1}$ & $\mathbf{u}_{2}$ & $\mathbf{u}_{3}$ \\
\hline FCS & 5.312 & 10.624 & 0.011 \\
\hline FT & 12.061 & 16.525 & 2.334 \\
\hline SEV & 5.290 & 1.417 & 1.933 \\
\hline
\end{tabular}

Source: iFIS ITB, own processing.

As three faculties are assessed, three models need to be created. Faculty efficiency is marked e and an order number.

The first faculty assessed in 2019 is FCS. The results show that FCS I efficient, since the value of $e_{1}$ is 1 . The important input for the model of FCS is $v_{2}-$ personnel costs (with a value of 0.045 ). The important source for the model of FCS is the output $\mathrm{u}_{2}$ - funds for pedagogical activities (with a value of 0.094). 
The second faculty assessed in 2019 is FT. The results show that FT is efficient, since the value of $e_{2}$ is 1 . The important inputs for the model of FT are $v_{2}-$ personnel costs (with a value of 0.015 ) and $v_{4}-$ services consumption (with a value of 0.079 ). The important sources are the outputs $\mathrm{u}_{1}$ - funds for creative activities (with a value of 0.026 ) and $\mathrm{u}_{2}$ - funds for pedagogical activities (with a value of 0.042 ).

The third faculty assessed in 2019 is SEV; the results show that SEV is efficient, since the value of $e_{3}$ is 1 . The important input for the model of SEV is $v_{2}-$ personnel costs (with a value of 0.128 ), while the important source is the output $\mathrm{u}_{1}$ - funds for creative activities (with a value of 0.189 ).

\section{Discussion}

To assess the efficiency of the ITB management, the data envelope analysis was carried out, which is used for assessing the management of sources of financing. The input-oriented CCR model was used since constant return on scale was assumed. There were identified efficient units, which were compared with the others. By analysis, the efficiency of individual ITB faculties (FCS, FT, SEV) in the period of 2017-2019 was assessed on the basis of four inputs and three outputs. The inputs included personnel costs, costs of material, services, and fixed assets (tangible and intangible). The outputs included funds for creative, pedagogical, and contract activities of the individual faculties. Appropriate selection of inputs and outputs plays an important role in terms of the informative capability of the analysis performed. To the analysis outputs, there should be always assigned the inputs that have links to the selected outputs. The monitored units are thus assessed on the basis of the resources used to achieve the outputs - inputs necessary to achieve the required results (outputs).

The analysis shows that in 2017 , not all faculties were efficient. This applies to FCS, since the value of $\mathrm{e}_{1}$ was lower than 1 . For this reason, a dual model was created, which enabled obtaining a suitable combination to achieve the efficiency of FCS and identification of the optimal value of inputs in comparison with FT and SEV (efficient faculties). The analysis also determined a required reduction of material consumption from the initial CZK 0.293 million to CZK 0.254 million, i.e. a reduction by CZK 39 thousand. In the case of personnel costs, the required reduction was by CZK 3.389 million (from CZK 24.402 million to CZK 21.013 million). No change was required in the case of fixed assets, as there was no purchase in that year. In the case of services consumption, the faculty was recommended to reduce the value from the initial CZK 2.990 million to CZK 2.589 million (by CZK 0.401 million). Both FT and SEV were efficient in that year, since the values of $e_{2}$ and $e_{3}$ was equal to 1.

The analysis for the years 2018 and 2019 confirmed the efficiency of all ITB faculties concerned, since the values of $\mathrm{e}_{1}, \mathrm{e}_{2}$, and $\mathrm{e}_{3}$ were equal to 1 in all cases.

The analysis shows that since 2018, the management of all ITB faculties has become more efficient.

\section{Conclusion}

The objective of the paper was to create a model of assessing the efficiency of UAS faculties based on the DEA method.

The basic model was created on the basis of the literary research; for this reason, the DEA method is mentioned in the definition of the objective of the paper. The specific model was described in the methodology part of the paper. The methodology also includes the procedure for the subsequent validation of the model on an example of a specific university and its faculties. The results clearly show that the model provides interesting findings easily applicable in practice. It could be stated that the faculties concerned work very efficiently. 
Nevertheless, there was a case when the situation was different. In such a case, the model enables us to identify the cause of inefficiency of a given organizational unit and the direction on which the attention of the faculty management should be focused. The objective of the paper was thus achieved.

There was thus created a model that allows universities to manage the individual organizational units on the basis of valid input data, providing outputs in the form of specific measures to be taken in order to increase the efficiency of their activities.

So far, the model has been validated on the example of one institution, the Institute of Technology and Business in České Budějovice. Although the results are considered very positive, it will be necessary to validate them on a larger sample of universities and thus modify the model to a form and state that is applicable and useful for all universities in the world. This is a topic of further research.

\section{References}

1. S. A shmarina, E. K andrashina, A.Z Zotova, M. V ochozka, Z. R owland, J. V rbka, P. Suler, Research on development trends and tendencies of the higher education system in Russia and in the world. $1^{\text {st }}$ ed. České Budějovice, Czech Republic: Institute of Technology and Business in České Budějovice, Samara State University of Economics (2018)

2. N. K. A vkiran, Investigating technical and scale efficiencies of A ustralian universities through data envelopment analysis. Socio-Economic Planning Sciences, 35(1), 57-80 (2001)

3. M . M . M ora, M . R. Espinosa, M . R. Delgado, A pproach of processes for the distribution of economic resources in public university of Ecuador. International Research Journal of Management, IT and Social Sciences, 5(1), 25-35 (2018)

4. C.-D. T. T. Tran, Cost efficiency - one size fits all? A university-level analysis of economies of scale and scope in V ietnamese higher education. Asia Pacific Journal of Education, 1-20 (2020)

5. M inistry of Education Y outh and Sports. Bílá kniha terciárniho vzdělávání [White book on tertiary education] [online], A vailable at: https://www.msmt.cz/reforma-terciarnihovzdelavani/bila-kniha (2009)

6. T. O. Kowang, S. A. Samsudin, L. K. Y ew, O. C. Hee, G. C. Fei, C. S. Long, Factors affecting car purchase intention among undergraduates in Malaysia. International Journal of Academic Research in Business and Social Sciences, 8(8), 80-88 (2018)

7. M. St. A ubyn, A. Pina, F. Garcia, J. Pais, Study on the efficiency and effectiveness of public spending on tertiary education, Economic Papers No. 390, European Comission (2009)

8. Q. Zhang, P. A. Clayton, S. M. Breznitz, The hope fulfilled? Measuring research performance of universities in the economic crisis. International Regional Science Review (2019)

9. V. M unteanu, N. A ndrei-Coman, Modern methods for underlying the revenue and expenses budget in higher education institutions from Romania based on the criteria of cost-efficiency. Procedia - Social and Behavioral Sciences, 15, 2445-2448 (2011)

10. P. Mikušová, Measuring the efficiency of the Czech Public higher education institutions: A $n$ application of DEA. Journal on Efficiency and Responsibility in Education and Science, 10(2), 58-63 (2017)

11. M. Abbott, C. Doucouliagos, The efficiency of Australian universities: A data envel opment analysis. Economics of Education Review, 22(1), 89-97 (2003) 
12. S. Kantabutra, J. C. S. Tang, Efficiency analysis of public universities in Thailand. Tertiary Education and Management, 16(1), 15-33 (2010)

13. M. Pietrzak, P. Pietrzak, J. Baran, Efficiency assessment of public higher education with the application of Data Envelopment A nalysis: The evidence from Poland. Online Journal of Applied Knowledge Management, 4(2), 59-73 (2016)

14. T. Klieštik, Quantification effectiveness activities traffic company by the rules of data envelopment analysis. E \& M Ekonomie a Management, 12(1), 133-145 (2009)

15. T. Klieštik, The application of mathematical modelling to predict the financial health of businesses. Proceedings of the Third International Conference on Economic and Business Management, 56, pp. 298-302 (2018)

16. A. T. Flegg, D. O. Allen, K. Field, T. W. Thurlow, Measuring the efficiency and productivity of B ritish universities: An application of DEA and the M almquist approach. University of the West of England, Department of Economics, series Discussion Papers, No. 304. (2003)

17. J. Jablonský, M. Dlouhý, Models for efficiency evaluation of decision making units. Politická Ekonomie, 52(2) (2004)

18. W. W. Cooper, L. M. Seidford, K. Tone, Data Envelopment Analysis - A comprehensive text with models, applications, references and DEA-solver software. N ew Y ork City, United States: Springer (2007) 